\title{
THE INFLUENCE OF PRINCIPAL MANAGERIAL COMPETENCY TOWARD TEACHERS PRODUCTIVITY WITH MEDIATION OF ORGANIZATIONAL CITIZENSHIP BEHAVIOR AND INTERPERSONAL COMMUNICATION
}

\author{
Fitriani Harahap \\ STKIP Tapanuli Selatan, Indonesia \\ harahapfitri86@yahoo.co.id
}

\author{
Rusdinal \\ State University of Padang, Indonesia \\ rusdinalhar@yahoo.com
}

\begin{abstract}
This research was aimed at determining the influence of principal managerial competency toward teachers productivity with mediation of Citizenship Behavior (OCB) and Interpersonal Communication in State Vocational High School (SMK) South Tapanuli, North Sumatera. This research was mix research. Instruments were questionaire, interview, observation and documentation. The sample was 175 teachers by using simple random sampling with Structural Equation Modelling (SEM) and AMOS program assistance. The findings showed that principal managerial competency has positif and significant effect on teacher productivity, organizational citizenship behavior (OCB), and interpersonal communication. Interpersonal communication has positif and significant effect on teacher productivity and organizational citizenship behavior (OCB). Organizational citizenship behavior (OCB) has positif and significant effect on teacher productivity.
\end{abstract}

Keywords: principal managerial competency, teachers productivity, organizational citizenship behavior, interpersonal communication

\section{INTRODUCTION}

Teachers are one element in the field of education that must play an active role and put his position as a professional in accordance with the growing demands of society. In this case the teacher is not solely as a teacher who transfers knowledge, but also as an educator who transfer the values as well as mentors who provide direction and guide students in learning. Completeness of the number of teachers and the quality of the teacher will affect the success of students in learning that led to improving the quality of education. For that teachers are required professionals in carrying out their duties.

Any educational endeavor such as curriculum replacement, development of teaching methods, the provision of facilities and infrastructure will only mean if it involves the teacher. In addition, teachers are positioned as the front guard in the implementation of teaching and learning process because the teacher holds a very strategic position in an effort to create competent graduates and qualified to meet the needs of professional Human Resources. Therefore, the quality of teachers needs to be improved and developed in accordance with current and future needs. Law No. 14 Year 2005 Chapter IV article 20 on teachers and lecturers states that the standard of work performance of teachers in carrying out their professional duties, teachers are obliged to plan lessons, carry out quality learning process and assess and evaluate learning outcomes.

The main task of the teacher is realized in teaching and learning activities is a form of teacher productivity. Increased teacher productivity will affect the quality improvement of Human Resources output generated in the process of education and learning. The quality of education and graduates is often seen as dependent on the role of teachers in the management of the teaching components used in the teaching and learning process in which they are responsible. To be able to achieve optimal learning results of course teachers must have and display maximum productivity during the learning process by adjusting the development of science and technology.

In Indonesia the learning process is regulated in the Minister of Education and Culture Regulation No. 65 of 2013 on Standard Process. In order to implement the standard of educational process, the teacher is required to have high productivity. Teacher productivity has a very big impact on the output quality of graduates. Therefore, high teacher productivity can improve learning achievement of learners. It can be interpreted that teacher productivity has a dominant role in giving birth to qualified graduates in the academic field and ready to compete in the world of work so that the graduates are able to fill the available employment or entrepreneurship.

Based on observations made by researchers, concluded that the productivity of teachers State Vocational School in South Tapanuli allegedly still not optimal. This occurs because there are indications that can reduce the productivity of teachers, including there are still teachers who have not felt the need in preparing semester programs and annual programs, most are still just preparing programs to meet administrative and bureaucratic obligations and not a few who tend to lack the understanding of the function of the program created.

In addition, there are still minimal teachers who can realize the annual program and semester program on teaching and learning activities. Based on supervisor data, teacher productivity is not maximally as expected, where some teachers have not done their job well. In the preparation of Learning Implementation Plan (RPP) and the process of implementation of learning there are still teachers who get the value of $\mathrm{C}$ where the value of $\mathrm{C}$ is in the category enough or under performance (Ministry Civil Servant Regulation No. 16 / 2009 Article 15). 
Then found the tendency of copy paste annual program from other teachers which of course the condition and learning situation of each learner is different, so it needs adjustment in the preparation of semester and annual program to support teaching and learning activities. Furthermore, in the implementation of teaching and learning activities found there are some teachers who have not been creative and still conventional in the delivery of a subject matter so that students feel bored and less attention. In teaching and learning activities only glued to the lecture method. Learning is still teacher-oriented. They use multimedia rarely in the learning process.

In addition to productivity, teachers are also expected to have an extra role in performing its functions as a teacher, because the task of teachers in addition to teaching but also educate, so that students have good character, and this problem often appears outside the hours such as students fighting during breaks, Stealing, cheating, being rude, bored. This problem cannot be ignored; the teacher should step in to solve it. In addition, to implement a quality learning process teachers are expected to be willing and willing to work with colleagues to form team teaching, discussing related to improving the quality of learning.

Collaborate on all things related to improving the quality of learning, respecting and loyal to the principal even though younger age, accepting all school decisions and regulations and running it as well as possible, this behavior is called organizational citizenship behavior (OCB). Organizational citizenship behavior ( $\mathrm{OCB}$ ) is a discretionary individual behavior in which a person who behaves extra does not directly gain rewards and rewards, and can also improve the efficiency and effectiveness of an organization (Organ, et al., 2006).

Teachers in carrying out their daily tasks will certainly relate to many people in the school either to students, principals or to fellow teachers. For that a teacher should also pay attention to his ability in communicating primarily in interpersonal communication. Interpersonal communication is a communication process that takes place between two or more persons personally. Rosenholtz (1989) states that relationships (interpersonal communication) with principals, colleagues, students and parents cannot be avoided by teachers in performing their duties. While Orebiyi (2011) stated that interpersonal communication between teacher and principal is very significant where support of leader (head of school) is needed by subordinate (the teacher).

Based on the background and problems that have been explained, the researcher is interested in doing research on principal managerial competency toward teacher productivity with mediation of organizational citizenship behavior (OCB) and interpersonal communication of State Vocational High School (SMK) South Tapanuli, North Sumatra.

\section{METHODS}

The place of study is the location or region where the research is conducted. The place is carried out this research in Vocational High School (SMK)
Affairs of South Tapanuli District of North Sumatra Province. Implementation of this research lasted for approximately seventeen months starting from the time of first data retrieval to completion of research data. Type of research used is a combination (mixed research). Mixed research is a research approach that combines or associates qualitative and quantitative forms (Creswell, 2014). Approach done in this research by using combination concurrent embedded method.

The sample size was 175 teachers distributed in 10 schools taken with simple random sampling. Quantitative data collection used in this study is a questionnaire. Meanwhile, the qualitative data collection used in this study is by interviewing, observation and documentation or often called triangulation. Descriptive analysis is used to analyze quantitative data. Where to describe the characteristics of each variable used percentage-percentage form. Furthermore, the average score of each indicator in the statements contained in the questionnaire used the following formula (Rianse, 2009).

Quantitative data analysis techniques used in this study is by the method of Structural Equation Modeling (SEM). Structural Equation Modeling (SEM) is a combination of two separate statistical methods of factor analysis and simultaneous equation modeling. Qualitative data analysis techniques used in this study is to follow the steps written by Miles and Huberman (1992).

\section{RESULTS AND DISCUSSION}

The average score of the principal managerial competency variable was 4.1965 with the respondent's level of achievement (CRA) of $83.93 \%$. The level of respondents' achievement (CRA) shows that the principal managerial competence variable is in good category. The average score of interpersonal communication variables is 4.0821 with the level of respondent achievement (CRA) of $81.64 \%$. The level of respondent achievement (CRA) shows that the interpersonal communication variables are in good category. The average score of the organizational citizenship behavior (OCB) variable was 4.1035 with the respondent's level of achievement (CRA) of $82.07 \%$. The level of respondent achievement (CRA) shows that organizational citizenship behavior (OCB) variable is in good category. The average score of teacher productivity variables is 4.0712 with the level of respondent achievement (CRA) of $81.42 \%$. The level of respondents' achievement (CRA) shows that teacher productivity variables are in good category. So it can be concluded that the productivity of teachers in State Vocational School South Tapanuli Regency is good.

Confirmatory factor analysis (CFA) is used to measure the dimensions that make up a factor. Confirmatory factor analysis reflects a measurement model where observed variables define a latent variable or variable (Ferdinand, 2002). The value of the loading factor coefficient of each indicator for all variables is said to be valid if the measurement model test results are at a significance level of $\geq 0.50$. The significance level $\geq 0.50$ is seen from the result of standardized 
regression weight on the output table of the AMOS program which is in standardized estimates condition of the model. In contrast, each indicator for all variables having an estimate value below the level of significance of $\leq 0.50$ then the indicator cannot describe the variables (Ferdinand, 2002). Of all the factors already meet the required criteria. Having obtained that all the loading factor is above 0.50 can be continued the structural model equation model (Structural Model). Structural equation model for principal managerial competence variable, organizational citizenship behavior (OCB), interpersonal communication and teacher productivity have unequal equation analysis result. When the model is declared unfavorable, there are some things to consider modifying the model by adding or removing connections / connections, adding variables (if data is available), and subtracting variables. In the initial modification, the model modification used in this study is to add connections / hyphens. The value of modification indices will change every time modification is made. The modification that will be done is to increase the connection between the error variables because the connection between the variables is no longer possible to do although there are still recommended by Amos. Testing of research hypothesis is done based on the results of causality relationship analysis among research variables, as presented in Table 1 below:

Table 1

Relationship analysis among research variables

\begin{tabular}{|c|c|c|c|c|c|}
\hline \multicolumn{6}{|c|}{ (1) } \\
\hline & & Estimate & C.R & & Explanation \\
\hline Teacher_Productivity & $<--\begin{array}{l}\text { Principal_Manajerial_ } \\
\text { Competency }\end{array}$ & 0.872 & 2.080 & 0.038 & Significant \\
\hline $\begin{array}{l}\text { Organizational_} \\
\text { Citizenship_Behavior }\end{array}$ & $<---\begin{array}{l}\text { Principal_Manajerial_ } \\
\text { Competency }\end{array}$ & 0.714 & 2.249 & 0.025 & Significant \\
\hline $\begin{array}{l}\text { Communication } \\
\text { Interpersonal }\end{array}$ & $<---\begin{array}{l}\text { Principal_Manajerial_ } \\
\text { Competency }\end{array}$ & 0.983 & 14.149 & 0.000 & Significant \\
\hline Teacher_Productivity & $<-\begin{array}{l}\text { Communication } \\
\text { Interpersonal }\end{array}$ & 0.691 & 2.218 & 0.042 & Significant \\
\hline $\begin{array}{l}\text { Organizational_} \\
\text { citizenship_behavior }\end{array}$ & $<--\begin{array}{l}\text { Communication_ } \\
\text { Interpersonal }\end{array}$ & 0.823 & 2.246 & 0.024 & Significant \\
\hline Teacher_Productivity & $<---\begin{array}{l}\text { Organizational_ } \\
\text { Citizenship_Behavior }\end{array}$ & 0.644 & 2.235 & 0.023 & Significant \\
\hline
\end{tabular}

Based on the data in Table 1 above, it is known that the value of principal managerial competence variable with teacher productivity variables shows that the value of C.R of 2.080 is greater than the critical value, that is $1.65(2.080>1.65)$. While p-value 0,038 smaller than $0,05(0.038<0.05)$ with coefficient equal to 0.872 . This means that the managerial competence variable of the principal has a positive and significant effect on teacher productivity variables in State Vocational School in South Tapanuli. Thus, the hypothesis stating that the principal managerial competence has a positive and significant effect on teacher productivity is proven. The amount of principal managerial competence contribution to teacher productivity is $87.2 \%$. This great influence proves that without the managerial competence of the principal the teacher's productivity will be low. This achievement cannot be separated from the principal's efforts to improve learning and learning activities by providing the necessary facilities and infrastructure.

The principal also requires teachers to prepare the lesson plan before implementing the teaching and learning process. However, the headmaster's efforts are still constrained by teachers who are still not preparing the lesson before entering the classroom to teach. Yet many teachers have received certification in exchange for additional salary provided by the government for improving the quality of learning in the classroom and to support the improvement of professionalism of teachers. Certification money received by teachers is widely used to meet the needs of luxury such as buying gold, cars, homes, accessories and other luxury needs.

Furthermore, the positive and significant impacts indicate that the principal's managerial competence is able to improve the willingness and ability of the teacher to prepare the planning of the learning process (using syllabus in designing the lesson plans, preparing the lesson planning plan, preparing the learning media, preparing the learning appraisal tool) Learning (conveying the nature and purpose of learning, using textbooks according to the needs of learners, adjusting the volume with the number of students and the room area, using polite words and languages that are easy to understand students, welldressed and polite when teaching in the classroom, creating discipline and discipline in the classroom, encouraging students to ask questions and express opinions, making the process of teaching and learning can change attitudes and behavior of students to a better, implementing the learning process in accordance with the allocated time allocation).

Assessment of learning outcomes (drawing conclusions from material taught, evaluating the learning process), follow-up (using assessment results for remedial and enrichment programs). Good managerial competence by the principal will improve teacher productivity in State Vocational School South Tapanuli. Increased teacher productivity can be seen from the RPP, the implementation of the learning process in accordance RPP, the assessment of learning 
outcomes and the follow-up of learning. Therefore, teacher productivity in State Vocational School South Tapanuli can be improved by increasing the managerial competence of the principal.

The findings of this study are in line with Besong's (2014) research results proving that an administrator significantly positively influences staff productivity (including teachers) through interpersonal relationships that manage school finances and motivation. Shamaki (2015) conducted a study at a junior high school level in Nigeria's Taraba state and concluded that the principal's democratic leadership can improve teacher work productivity. Furthermore, Harris, et al. (2010) conducted research on teachers funded by the United States Department of Education, which showed that teaching skills contribute the most to school principals in influencing teacher productivity. While the ability of the principal in cooperation with others and interpersonal skills have a significant influence but lower than the teaching skills.

The results of this study are also consistent with a study conducted by Mulford (2003) who found that principal leadership affects teachers and school effectiveness. Principals play a role in building teachers' determination and teacher capacity to achieve common goals. Azis (2014) proves that his research findings indicate that the principal's managerial competence can improve teacher productivity to improve the quality of education at SMAN I Gunung Sindur. Thus, teachers' productivity can be affected by the principal's managerial competence. The increased teacher productivity can be seen from the Lesson Plans (RPP), the implementation of the learning process according to the lesson plan, the assessment of learning outcomes and the follow-up of learning. Therefore, teacher productivity in State Vocational School South Tapanuli can be improved by increasing the managerial competence of the principal.

Based on the data in Table 1 above, it is known that the value of the principal managerial competence variable with organizational citizenship behavior (OCB) variable shows that the value of C.R 2,249 is greater than the critical value of $1.65(2.249>1.65)$. While p-value 0.025 smaller than $0.05(0.025<0.05)$ with coefficient equal to 0,714 . This means that the managerial competence variable of the principal has a positive and significant effect on the organizational citizenship behavior (OCB) variable in State Vocational School South Tapanuli Regency. Thus, the hypothesis that managerial competence has a positive and significant effect on organizational citizenship behavior (OCB) is proven. The amount of principal managerial competence contribution to organizational citizenship behavior (OCB) is $71.4 \%$.

This can be known from the coefficient of influence of principal managerial competence on organizational citizenship behavior (OCB) of 0.714 . The existence of this influence is evidenced by the willingness of the principal to reward teachers who have extra behavior in school. The principal also continues to motivate teachers to do more for the school. However, the principal's efforts to cultivate the willingness and willingness of teachers to behave extra has not been fully welcomed by teachers positively. This is due to the fact that teachers who want to work or do more for the school must be in return (money).

These positive and significant influences indicate that the principal's managerial competence is capable of generating volunteerism to help co-workers despite their work duties, maintaining good relationships with fellow workers, and accepting any policies and procedures established by the organization thereby increasing organizational citizenship behavior (OCB) among teachers at State Vocational School South Tapanuli. The increased organizational citizenship behavior (OCB) of the teacher can be seen from the dedication of the teacher to complete the task prematurely, reporting to the employer or co-worker first when not in work, and increasing the teacher's sense of responsibility to comply with school rules and regulations even under no conditions There is nobody who watches, care about the development and changes that occur in the organization and participate in various activities organized by the organization. Therefore, the organizational citizenship behavior (OCB) of teachers in State Vocational School South Tapanuli can be improved by increasing the managerial competence of the principal.

The findings of this study are in line with the results of Moreno's (2014) study which proves that the principal affects the teacher's organizational citizenship behavior (OCB). Teacher behavior is influenced by three basic elements of leadership, namely: interpersonal leadership, instructional leadership, and transformational leadership. Furthermore, Oplatka (2013) conducted a study of 30 teachers and 10 principals. The results showed that the principal affects the teacher's organizational citizenship behavior (OCB). The teacher's organizational citizenship behavior (OCB) is influenced by the principal's ability to provide the teacher's needs, provide support to teachers, and express positive emotions including giving positive feedback to teachers who have transcended formal roles at work.

The results of this study are also consistent with the research of Somech and Ron (2007) who conducted research to prove that principals have a positive relationship to organizational citizenship behavior (OCB) in which the individual character of a principal is able to influence organizational citizenship behavior (OCB) in school. His research showed significant results. The results of this study are also reinforced by the results of research conducted by Dipaola, et al., (2001) who found a strong relationship between organizational citizenship behavior (OCB) with school climate. Where one of the dimensions of school climate that strengthens organizational citizenship behavior (OCB) is collegial leadership. Similarly, research conducted by Bogler (2004) where the results of his research to prove that the principal can motivate teachers to increase organizational citizenship behavior (OCB) for the benefit of school.

Furthermore, the principal tries to increase the extra behavior of teachers in school. Anything that teachers do outside of the principal's learning is very appreciative of the good scouts, art, religious, and 
others that support for the development of students. Although in essence extra behavior is a behavior that arises from a teacher without expecting rewards and rewards but the principal still appreciate the extra teacher's behavior.

Based on the data in Table 1 above, it is known that the value between principal managerial competence variables and interpersonal communication variables shows that the value of C.R 14.149 is greater than the critical value of $1.65(14.149>1.65)$. While $p$ value 0.000 is smaller than $0.05(0.000<0.05)$ with a coefficient of 0.983 . This means that the managerial competence variable of the principal has a positive and significant influence on the interpersonal communication variables in State Vocational School South Tapanuli. Thus, the hypothesis stating that the principal managerial competence has a positive and significant influence on proven interpersonal communication. The amount of principal managerial competence contribution to interpersonal communication is $98.3 \%$.

It can be known from coefficient value of principal managerial competence influence to interpersonal communication 0.983 . The positive influence of school principals on teacher interpersonal communication is also evidenced by the communications constructed by the headmaster with the whole lot of people by acting on familial communication known in South Tapanuli regency as tutur poda. Tutur poda is a name or a call to others who are familial (Nature, 2011: 1). The principal gives an example in the execution of tutur poda as well as suggesting the teachers to use tutur poda both to fellow teachers and students.

These positive and significant influences also indicate that the principal's managerial competence is able to generate mutual openness among teachers, to accept criticism, and to feel what other teachers feel as a friend communicate, thus improving interpersonal communication among teachers at State Vocational School Tapanuli South. Improved interpersonal communication of teachers can be seen from the availability of teachers to provide motivation to other teachers, be positive towards other teachers, and the recognition of equality between the two parties in interpersonal communication (interpersonal) .Therefore, interpersonal communication of teachers in State Vocational School South Tapanuli can be improved by increasing the principal's managerial competence.

The findings of this study are in line with the results of research conducted by Rowicki (1999) to prove that the principal in leading the school must master the ability to communicate in conveying ideas, or news to the school community. The success or failure of the school depends largely on the effectiveness of the communication the principal has built. Price (2015) conducts research on charter schools in the United States. The results showed a positive relationship in interaction (interpersonal communication) between principal and teacher by involving students. Ärlestig (2008) states that principals and teachers should prioritize and improve the quality of communication between them. Principal communication with teachers should also be distributed proportionally. Where the principal gives more time to the teacher in need of problem solving as this can be the strength of an organization.

The results of this study are also consistent with research Williamson (2007) found that there is a positive relationship between the principal and teachers in communicating for the creation of a healthy school climate and open. Research conducted by Oswalt (2011) in elementary schools in urban areas in Nevada, USA obtained research results that revealed a positive relationship between headmaster communication with school climate including teachers. Technological advancements allow principals and teachers to communicate more frequently through communication channels without direct face-to-face, such as email usage, cell phones. Research conducted by Halawah (2005) in the Abu Dhabi District of the United Arab Emirates found that effective communication between school principals and teachers is needed to provide a better school climate. In this study also found that communication between principals and male teachers is more effective than female teachers.

To establish good communication with the teachers, the principal is guided by the kinship nature as in South Tapanuli area known as tutur poda. This tutur poda is a culture that develops in a society that has its own value as when calling a father with a call $u d a$, of course call $u d a$ closer. The principal keeps using the speech even at school. So the headmaster to call siswapun with the call amang, host, so the principal also urged the teachers to use the tutur poda to the students to feel more kinship.

Based on the data in Table 1 above, it is known that the value of interpersonal communication variables with teacher productivity variables shows that the value of C.R 2.218 is greater than the critical value of 1.65 $(2.218>1.65)$. While p-value 0.042 less than 0.05 $(0.042<0.05)$ with coefficient equal to 0,691 . This means that the variables of interpersonal communication have a significant influence on teacher productivity variables in State Vocational School South Tapanuli. Therefore, the hypothesis that interpersonal communication has a positive and significant effect on teacher productivity is proven. The magnitude of the contribution of interpersonal communication to teacher productivity is $69.1 \%$. It can be known from the coefficient value of interpersonal communication effect on teacher productivity of 0.691 . The results of this study indicate that the situation and working environment conditions that can lead to openness, sense of responsibility, dedicated, proven it has a real impact on the high level of teacher productivity. In this case, the high or low level of interpersonal communication of teachers will have a major impact on teacher productivity.

The results of this study are in line with research conducted in Philippine institutions of higher education by Narzoles (2012) proves that communication affects the productivity of institutions including teachers. Narzoleh proves good interpersonal communication will increase the productivity of school residents 
including teachers. Good interpersonal communication will create a comfortable school environment and cause a sense of happiness in the heart of the teacher and get peace in work, happiness gained in the work environment impact on improving teacher work, conversely if there is discomommunication will be easy to create disputes between teachers. (2008) states that the quality of communication can affect the productivity of teachers and principals. Good communication between school principals and teachers should be maintained for the improvement of school or organizational goals.

Adeyemi (2016) shows that there is a significant relationship between communication and teacher performance. Where the dimensions of effective communication significantly affect the performance of teachers. Teacher performance can be affected or inhibited by effective communication applied in schools. The results of research conducted by Kambeya (2008) also found that the effective interpersonal communication skills of a principal can affect teachers' performance whether it is the quality of work, attitudes, and behavior of teachers. Differences in quality of work, attitudes, achievements and behavior of teachers cause the results of this study is not In line with previous research. Further Johnson's research (1994) by sending questionnaires to samples of approximately 1.000 principals asked them to assess the abilities, factors, and programs related to teacher selection, teacher evaluation, and teacher preparation. The results of his research indicate that communication skills are the highest determinants in relation to teacher recruitment.

Based on the data in Table 1 above, it is known that the value between interpersonal communication variables and organizational citizenship behavior (OCB) variables shows that the value of C.R 2.246 is greater than the critical value of $1.65(2.246>1.65)$. While p-value 0.024 smaller than $0.05(0.024<0.05)$ with coefficient equal to 0.823 . This mean interpersonal communication variable have significant influence to organizational citizenship behavior variable (OCB) in State Vocational School South Tapanuli. Therefore, the hypothesis that interpersonal communication has a positive and significant effect on Organizational Citizenship Behavior (OCB) is proven. The magnitude of the contribution of interpersonal communication to organizational citizenship behavior (OCB) is $82.3 \%$. It can be known from the coefficient value of the influence of interpersonal communication to organizational citizenship behavior (OCB) of 0.823 .

The results of this study indicate that the work environment conditions and conditions that can lead to openness, sense of responsibility, dedication, it is proven to have a real impact on the high level of organizational citizenship behavior (OCB) teachers. In this case, the higher the teacher's interpersonal communication, the higher the organizational citizenship behavior (OCB) of the teacher. This condition can occur because if good interpersonal communication of teachers will be able to encourage teachers to have high dedication to complete the task prematurely, report to superiors or colleagues in advance when not in work, and increased sense of responsibility of teachers to comply with the rules and regulations School in spite of the fact that no one is watching, concerned about the progress and changes that occur within the organization and participates in various activities organized by the organization. Situations like this will have a positive impact on improving school quality.

The results of this study are in line with research conducted by Ali (2010) which proves that communication satisfaction (interpersonal, group, organization) is one factor that can affect organizational citizenship behavior (OCB) although many studies have found that job satisfaction is the most predictor Great against organizational citizenship behavior (OCB). From the results of his research can be understood that good interpersonal communication will impact on organizational citizenship behavior (OCB) which is seen from the more dedication shown to the school, voluntary nature, good relationships, willingness to accept organizational decisions, have a high dedication and sense Teacher responsibilities.

Furthermore, the results of studies conducted by Brown and Roloff (2015) also showed a positive relationship between communication with organizational citizenship behavior (OCB), meaning that the better the teacher interpersonal communication the better the organizational citizenship behavior (OCB). Because teachers will be more motivated to increase their organizational citizenship behavior (OCB) if they have the support and encouragement of peers, on the contrary if the communication is not good will create incompetence among them. The findings of this study also in accordance with the research conducted by Ozsaker, et al., (2012) states that the level of organizational communication directly influences organizational culture and organizational climate, healthy organizations can strengthen organizational citizenship behavior (OCB) such as informing, Work overtime, volunteer work, and so on. Osman (2014) in his research found that between the dimensions of organizational communication, only the dimensions of communication with managers were significantly correlated with altruism and civic virtue against organizational citizenship behavior (OCB).

According to the results of research conducted by Herfina, et al., (2015) proved that interpersonal communication also positively affect the organizational citizenship behavior (OCB). These findings indicate that interpersonal communication is the delivery of messages and the exchange of direct and face-to-face information between individuals as well as generate feedback that can make the message easy to understand and can be delivered correctly.

Based on the data in Table 1 above, it is known that the value of organizational citizenship behavior (OCB) variable with teacher productivity variables shows that the value of C.R 2.235 is greater than the critical value, that is $1.65(2.235>1.65)$. While $\mathrm{p}$-value 0.023 smaller than $0.05(0.023<0.05)$ with coefficient equal to 0,644 . This means organizational citizenship behavior (OCB) variable significant to teacher productivity variables in State Vocational School South 
Tapanuli. Therefore, the hypothesis that organizational citizenship behavior (OCB) has a positive and significant effect on teacher productivity is evident. The high organizational citizenship behavior (OCB) will encourage teachers to prepare lesson planning (using syllabus in designing lesson plans, preparing lesson plans for teaching learning activities, preparing instructional media, preparing learning appraisal tools), process implementation learning (conveying the nature and purpose of learning, using textbooks according to the needs of learners, adjusting the volume with the number of students and the room area, using polite words and languages that are easy to understand students, well-dressed and polite when teaching in the classroom, creating discipline and discipline in the classroom, encourage students to ask questions and express opinions, make teaching and learning process can change attitudes and behavior of students to a better, implement the learning process in accordance with the allocated time allocation), assessment of defendants (Making conclusions from the taught material, evaluating the learning process), follow-up (using assessment results for remedial and enrichment programs).

Increased teacher productivity can be seen from the RPP, the implementation of the learning process in accordance RPP, the assessment of learning outcomes and the follow-up of learning. Therefore, teacher productivity in State Vocational School South Tapanuli can be improved by increasing the organizational citizenship behavior (OCB) of teachers. These positive and significant influences indicate that organizational citizenship behavior (OCB) is capable of generating volunteers to help co-workers despite their work duties, maintaining good relationships with fellow workers, and accepting any policies and procedures established by schools that will increase productivity Teacher at State Vocational School South Tapanuli. The increased teacher productivity can be seen from the teacher's dedication to complete the task prematurely, reporting to the boss or co-worker first when not in work, and increasing the teacher's sense of responsibility to comply with school rules and regulations even under no circumstances, Care about the development and changes that occur in the organization and participate in various activities organized by the organization. Therefore, teacher productivity in State Vocational School South Tapanuli can be improved by increasing the willingness of teachers to do more to the school (organizational citizenship behavior / OCB).

The findings of this study are in line with the results of research conducted by Ajayi (2012) revealed that there is a significant relationship between the OCB's extra behavior (participation) of teachers in school management on their productivity. This is due to the fact that teachers are allowed to behave in extraOCB (participation) in their school management will have a sense of belonging. Furthermore, Khazei et al. (2011) also shows that there is a significant correlation between the behavior of organizational citizens and teacher productivity and between the behavioral components of organizational citizens and teacher productivity. Table 2 below reveals the direct and indirect effects of managerial competence variables, teacher productivity, organizational citizenship behavior (OCB), and interpersonal communication.

Table 2

Influence Directly, Indirectly and Total Influence

\begin{tabular}{lccccccccc}
\hline \multirow{2}{*}{\multicolumn{1}{c}{ Variabel }} & \multicolumn{3}{c}{$\begin{array}{c}\text { Principal Manajerial } \\
\text { Competency }\end{array}$} & \multicolumn{2}{c}{$\begin{array}{c}\text { Interpersonal } \\
\text { Communication }\end{array}$} & \multicolumn{2}{c}{$\begin{array}{c}\text { Organizational Citizenship } \\
\text { Behavior (OCB) }\end{array}$} \\
\cline { 2 - 9 } & Directly & Indirectly & Totally & Directly & Indirectly & Totally & Directly & Indirectly & Totally \\
\hline Teacher Productivity & 0.872 & 0.066 & 0.938 & 0.691 & 0.017 & 0.708 & 0.644 & - & 0.644 \\
Organizational Citizenship Behavior & 0.714 & - & 0.714 & 0.823 & - & 0.823 & - & - & - \\
Interpersonal Communication & 0.983 & - & 0.983 & - & - & - & - & - & - \\
\hline
\end{tabular}

Table 2 above shows that the principal managerial competence has a direct influence on the productivity of 0.872 teacher as larger than the indirect effect on teacher productivity in State Vocational School South Tapanuli of 0.066 so that the total influence of principal managerial competence on teacher productivity is 0.938 . Thus organizational citizenship behavior (OCB) can increase the influence of principal managerial competence on teacher productivity. That is, to improve teacher productivity, the principal should be able to increase the organizational citizenship behavior (OCB) teachers in schools. The result of the test shows that there is an increasing influence of principal managerial competence on teacher productivity through organizational citizenship behavior (OCB) mediation variable. To increase teachers' productivity in State Vocational School in South Tapanuli, the determining factor is the principal's managerial competence but the influence will increase if the principal is able to increase the teacher's organizational citizenship behavior (OCB).

Table 2 shows that the principal managerial competence has a direct effect on the productivity of 0.872 teacher as larger than the indirect influence on teacher productivity in State Vocational School South Tapanuli of 0.066 so that the total influence of principal managerial competence on teacher productivity is 0.938 . Thus interpersonal communication can increase the influence of principal managerial competence on teacher productivity. That is, to improve teacher productivity, principals must be able to improve interpersonal teacher communication. To increase teachers' productivity in State Vocational School in South Tapanuli, the determining factor is the managerial competence of the principal, but the 
influence will increase if the principal is able to improve teacher interpersonal communication. Principal managerial competence has a direct influence on teacher productivity, but the effect is greater if through interpersonal communication mediation variables.

Table 2 shows that interpersonal communication has a direct effect on 0.691 teachers productivity, greater than the indirect effect on teacher productivity in State Vocational School South Tapanuli of 0.017 so that the total effect of interpersonal communication on teacher productivity is 0.708 . Thus organizational citizenship behavior (OCB) can increase the effect of interpersonal communication on teacher productivity. That is, teacher productivity can increase if organizational citizenship behavior (OCB) is also increasing, where teacher organizational citizenship behavior (OCB) also increases if interpersonal communication can be improved. Based on the testing of mediation variables, it is evident that organizational citizenship behavior (OCB) variable is a mediating variable. The results of the test show that there is an increasing influence of interpersonal communication on teacher productivity through organizational citizenship behavior (OCB) mediation variable. To increase teachers' productivity in State Vocational School in South Tapanuli, which becomes one of the determinants is interpersonal communication but its influence will increase if through increased organizational citizenship behavior (OCB). As evidenced by the increasing influence of interpersonal communication on teacher productivity if through organizational citizenship behavior (OCB).

\section{CONCLUSION}

Based on the discussion in the previous chapter it can be concluded several things as follows:

1. Principal managerial competence has a positive and significant effect on teacher productivity. So it can be stated that the higher the managerial competence of the principal, the higher the level of teacher productivity in State Vocational School South Tapanuli. Vice versa, the lower the managerial competence of the principal, the lower the productivity of teachers in State Vocational School South Tapanuli. This achievement cannot be separated from the principal's efforts to improve learning and learning activities by providing the necessary facilities and infrastructure. The principal is also able to encourage the teacher to prepare the planning of the learning process (using syllabus in designing RPP, preparing RPP for the PBM activity, preparing instructional media, preparing the learning appraisal tool), implementation of learning process.

2. Principal managerial competence has positive and significant impact on organizational citizenship behavior (OCB). So it can be stated that the higher the managerial competence of the principal then the higher the level of organizational citizenship behavior (OCB) teachers in State Vocational School in South Tapanuli Regency. Similarly, the lower the managerial competence of the principal, the lower the organizational citizenship behavior (OCB) teachers in State Vocational School South Tapanuli. The principal is capable of generating volunteerism of teachers helping co-workers despite their work duties, maintaining good relationships with fellow teachers, and accepting any policies and procedures established by the school. The increased organizational citizenship behavior (OCB) of the teacher can be seen from the teacher's dedication to complete the task prematurely, reporting to the boss or co-worker first when not in work, and increasing the teacher's sense of responsibility to comply with school rules and regulations even under no conditions There is nobody who watches, care about the development and changes that occur in the organization and participate in various activities organized by the organization.

3. Principal managerial competence has a positive and significant influence on interpersonal communication. So it can be stated that the higher the managerial competence of the principal then the higher the level of teacher interpersonal communication. Vice versa, the lower the managerial competence of the principal, the lower the level of interpersonal communication of teachers in State Vocational School South Tapanuli. Principals are able to generate mutual openness among teachers, willing to accept criticism, and feel what is felt by other teachers as friends communicate. Increased interpersonal communication can be seen from the availability of teachers to provide motivation to other teachers, to be positive, and the recognition of equality between the two parties in interpersonal (interpersonal).

4. Interpersonal communication has a positive and significant effect on teacher productivity. This means that meaningful interpersonal communication to teacher productivity. In this case, the existence of good interpersonal communication among teachers, then the teachers will have high productivity. This is due to the mutual help and good communication among the teachers in the process of preparing the planning, implementation, evaluation and follow-up learning according to lawsuits so that the variables of interpersonal communication meaningful to teacher productivity.

5. Interpersonal communication has a positive and significant effect on organizational citizenship behavior (OCB). This means that interpersonal communication is meaningful to organizational citizenship behavior (OCB). In this case, the existence of good interpersonal communication among teachers will increase the organizational citizenship behavior (OCB) of teachers to their work. Teachers generate a sense of volunteering to help co-workers despite their work duties, maintaining good relationships with fellow workers, and accepting any policies and procedures established by the organization, this has been shown to have an impact on their organizational citizenship behavior (OCB). Teachers will have extra behavior toward their organizations because 
teachers have the dedication to complete tasks prematurely, report to superiors or co-workers in advance when not in work, and increased teacher's sense of responsibility to comply with school rules and regulations even in the absence of a person Who are watching, care about the development and changes that occur in the organization and participate in various activities organized by the school.

6. Organizational citizenship behavior (OCB) has a positive and significant effect on teacher productivity. This means that Organizational citizenship behavior (OCB) is meaningful to teacher productivity. In this case, the teacher's organizational citizenship behavior (OCB) will have an impact on its productivity. Teachers will have high productivity if organizational citizenship behavior (OCB) is high. This is due to the fact that teachers work according to the standard process to prepare planning, implementation, evaluation and follow-up learning according to lawsuit so that the variable of organizational citizenship behavior (OCB) is significant to teacher productivity.

7. Principal managerial competence has influence on teacher productivity through organizational citizenship behavior (OCB) mediation variable. This can increase the influence of principal managerial competence on teachers' productivity. Therefore, in addition to managerial competence, the principal also needs to improve the teacher's organizational citizenship behavior (OCB).

8. Principal managerial competence has an effect on teacher productivity through interpersonal communication mediation. This can increase the influence of principal managerial competence on teachers' productivity. Therefore, the principal should pay attention also to improve teacher interpersonal communication.

9. Interpersonal communication has an effect on teacher productivity through organizational citizenship behavior (OCB) mediation variable where proven interpersonal communication can add influence to teacher productivity through organizational citizenship behavior (OCB).

\section{REFERENCES}

[1] Adeyemi, K. J. 2016. Influence of Communication on Teachers' Job Performance. Tai Solarin University of Education: Ijagun. Retrieved August 26, 2016, from https://www.academia.edu/6789084/INFLUENCE_OF _COMMUNICATION_ON_TEACHERS_JOB_PERF ORMANCE.

[2] Alam, S. T. P. 2011. Tutur Poda. Tapanuli Selatan: Mitra.

[3] Ali, A. J. 2010. Organizational Citizenship Behavior in Concern of Communication Satisfaction: The Role of the Formal and Informal Communication. International Journal of Business and Management, 5(10), 51-61.

[4] Ärlestig, H. 2008. Communication between Principals and Teachers in Successful Schools. Dissertation unpublished. Sweden: Umeå Universitet.

[5] Azis, A. 2014. Principal's Trilogy Leadership Style and Teacher Productivity in Islamic Elementary School of East Java Province, Indonesia. Dissertation unpublished. Malang: UIN Maulana Malik Ibrahim.

[6] Besong, J. 2014. Principals' Administrative Effectiveness and Staff Productivity in Selected Secondary School in South West Region, Cameroon. International Journal of Academic Research in Management (IJARM), 3(2) 155-166.

[7] Bogler, R., and Somech, A. 2004. Influence of Teacher Empowerment on Teachers' Organizational Commitment, Professional Commitment and Organizational Citizenship Behavior in Schools. Teaching and Teacher Education, 20, 277-289.

[8] Brown, L. A. \& Michael E. R. 2015. Organizational Citizenship Behavior, Organizational Communication, and Burnout: The Buffering Role of Perceived Organizational Support and Psychological Contracts. Journal Communication Quarterly, 63, 384-404. Retrieved August 26, 2016, from http://www.tandfonline.com/doi/pdf/10.1080/01463373 .2015.1058287.

[9] Creswell, J. 2009. Research Design Qualitative, Quantitative, and Mixed. Yogyakarta: Pustaka Pelajar.

[10] Dipaola, Michael, and Moran. 2001. Organizational Citizenship Behavior in Schools and Its Relationship to School Climate. Journal of School Leadership, 11, 424447.

[11] Ferdinand, A. 2002. Structural Equation Modelling in Management Research. Semarang: FE UNDIP.

[12] Halawah, I. 2005. The Relationship between Effective Communication of High School Principals and School Climate. Education, 126, 334-345. Retrieved August 16, 2016, from https://www.questia.com/library/journal/1G1$142057921 /$.

[13] Harris, D. N., and Sass, T. R. 2010. What Makes for a Good Teacher and Who can Tell? Retrieved August 20, 2016, from http://myweb.fsu.edu/tsass/Papers/IES\%20Harris\%20S ass\%20Principal\%20Eval\%2034.pdf.

[14] Herfina, T. A., and Rubini, B. 2015. The Relationship among Transformational Leadership, Work Satisfaction, and Interpersonal Communication to Teachers' Organizational Citizenship Behavior. International Journal of Managerial Studies and Research, 3, 11-16.

[15] Johnson, S. 1994. A National Assessment of Secondary-School Principals' Perceptions of TeachingEffectiveness Criteria. Communication Education, 43, 1-16. Retrieved August 21, 2016, from http://www.natcom.org/uploadedFiles/More_Scholarly Resources/Chairs_Corner/.pdf.

[16] Kambeya, N. V. 2008. Georgia Teachers' Perceptions of Principals' Interpersonal Communication Skills as They Relate to Teacher Performance. Dissertation unpublished. Georgia: Georgia Southern University.

[17] Law of the Republic of Indonesia Number 14 Year 2005 on Teachers and Lecturers. Bandung: Citra Umbara.

[18] Miles, M. B., dan Huberman, A. M. 1992. Qualitatif Data Analysis. Jakarta: Universitas Indonesia.

[19] Ministry Rule of Civil Servant No. 16 Year on Chapter 15. Bandung: Citra Umbara.

[20] Ministry Rule of Education and Culture No. 65 Year 2013. Bandung: Citra Umbara.

[21] Moreno, E. A. 2014. Organizational Citizenship Behavior in Schools:The Principal's Influence. Dissertation unpublished. San Diego: San Diego State University

[22] Mulford, B. 2003. School Leaders: Challenging Roles and Impact on Teacher and School Effectiveness. 
Retrieved August 21, 2016, from http://www.oecd.org/edu/school/37133393.pdf.

[23] Oplatka, I. 2013. The Principal's Role in Promoting Teachers' Extra-Role Behaviors: Some Insights From Road-Safety Education. Journal Leadership and Policy in Schools, 12, 420-439.

[24] Orebiyi, T. P. 2011. The Influence of Interpersonal Communication on Secondary School Teachers Job Satisfaction and Commitment in Kogi State Nigeria. Journal of Communication and Culture: International Prespective, 2(1), 109-117.

[25] Organ, D. W., Podsakoff, P. M., and MacKenzie, S. B. 2006. Organizational Citizenship Behavior: its Nature, Antecedents, and Consequences. New York: SAGE Publications.

[26] Osman, Y. 2014. The Impact of Organizational Communication on Organizational Citizenship Behavior: Research Findings. Journal Procedia Social and Behavioral Sciences, 150(15), 1095-1100.

[27] Oswalt, R. 2011. A Mixed Methods Exploration of Principal Communication and School Climate. Dissertation unpublished. Las Vegas: University of Nevada.

[28] Ozsaker, M., Nilay, O., and Orgun, F. 2012. A Study of the Organizational Citizenship Behaviors and Organizational Communications of Teachers: Case study of Aydin Province. African Journal of Business Management, 6(29), 8659-8666.

[29] Price, H. E. 2015. Principals' Social Interactions with Teachers: How Principal-Teacher Social Relations Correlate with Teachers' Perceptions of Student Engagement. Journal of Educational Administration, 53(1), 116-139. Retrieved August 16, 2016, from http://www.emeraldinsight.com/doi/abs/10.1108/JEA02-2014-0023/.

[30] Rianse, U. A. 2009. Social Research Methodology and Economic Teory and Aplication. Bandung: Alfabeta.

[31] Rosenholtz, S. J. 1989. Workplace Conditions that Affect Teacher Quality and Commitment. The Elementary School Journal, 89(4), 421-439.

[32] Rowicki. 1999. Communication Skills for Educational Administrators. Retrieved August 17, 2016, from http://files.eric.ed.gov/fulltext/ED432830.pdf\#page=3\& zoom=auto, $-101,738$.

[33] Shamaki, E. B. 2015. Influence of Leadership Style on Teacher's Job Productivity in Public Secondary Schools in Taraba State, Nigeria. Journal of Education and Practice, 6(10), 200-205.

[34] Somech, A., and Ron, I. 2007. Promoting Organizational Citizenship Behavior in Schools: The Impact of Individual and Organizational Characteristics. Educational Administration Quarterly, 43(1), 38-66.

[35] Williamson, J. S. 2007. Defining the Relationship between Principal's Leadership Style and School Climate as Perceived by Title I Elementary Teachers. Dissertation unpublished. Ohio: University of Toledo. 